\title{
JOHN MILES FOLEY'S WORLD OF ORALITIES
}




\section{BORDERLINES}

Borderlines welcomes monographs and edited collections that, while firmly rooted in late antique, medieval, and early modern periods, are "edgy" and may introduce approaches, methodologies, or theories from the social sciences, health studies, and the sciences. Typically, volumes are theoretically aware whilst introducing novel approaches to topics of key interest to scholars of the pre-modern past. 


\title{
JOHN MILES FOLEY'S WORLD OF ORALITIES \\ TEXT, TRADITION, AND \\ CONTEMPORARY ORAL THEORY
}

\author{
edited by \\ Mark C.Amodio
}

ARChumanities press 


\section{British Library Cataloguing in Publication Data}

A catalogue record for this book is available from the British Library.

\section{(C) 2020, Arc Humanities Press, Leeds}

Copyrighted work available under Creative Commons Attribution only licence CC BY 4.0.

The authors assert their moral right to be identified as the authors of their part of this work.

Permission to use brief excerpts from this work in scholarly and educational works is hereby granted provided that the source is acknowledged. Any use of material in this work that is an exception or limitation covered by Article 5 of the European Union's Copyright Directive (2001/29/EC) or would be determined to be "fair use" under Section 107 of the U.S. Copyright Act September 2010 Page 2 or that satisfies the conditions specified in Section 108 of the U.S. Copy-right Act (17 USC $\S 108$, as revised by P.L. 94-553) does not require the Publisher's permission.

ISBN (HB): 9781641893381

ISBN (PB): 9781641894593

e-ISBN: 9781641893398

\section{www.arc-humanities.org}

Printed and bound in the UK (by CPI Group [UK] Ltd), USA (by Bookmasters), and elsewhere using print-on-demand technology. 